\title{
Determination of Some Elements in Legumes Using ICP-MS and EDXRF Methodology Applications
}

\author{
Lovro Sinkovič, ${ }^{1,{ }^{*}}$ Marijan Nečemer, ${ }^{2}$ Barbara Pipan ${ }^{1}$ \\ and Vladimir Meglič ${ }^{1}$ \\ ${ }^{1}$ Crop Science Department, Agricultural Institute of Slovenia, Hacquetova ulica 17, SI-1000 Ljubljana, Slovenia \\ ${ }^{2}$ Department of Low and Medium Energy Physics, "Jožef Stefan" Institute, Jamova 39, SI-1000 Ljubljana, Slovenia \\ * Corresponding author: E-mail: lovro.sinkovic@kis.si \\ phone: $+386(0) 12805278$
}

Received: 08-16-2021

\begin{abstract}
The current study involves two analytical research techniques, inductively coupled plasma-mass spectrometry (ICP-MS) and energy dispersive X-ray fluorescence (EDXRF) spectroscopy, used to determine the elemental composition of different legumes usually produced and consumed in Slovenia. Results indicate that data obtained using these methods are in agreement with certified reference materials. In total, nineteen elements were determined from twenty legume samples. An intercomparison between four macro- (P, S, K, Ca) and three microelements (Fe, $\mathrm{Zn}, \mathrm{Mo}$ ) measured using ICP-MS and EDXRF methods showed a strong correlation. The EDXRF was found to be a cheaper, simpler and more environmentally friendly method for determination of elements $\mathrm{P}, \mathrm{S}, \mathrm{Cl}, \mathrm{K}, \mathrm{Ca}, \mathrm{Fe}, \mathrm{Zn}, \mathrm{Mo}, \mathrm{Sr}, \mathrm{Rb}, \mathrm{Ti}$ and $\mathrm{Br}$ in legumes, while for the identification and determination of $\mathrm{Na}, \mathrm{Mg}, \mathrm{V}, \mathrm{Cr}, \mathrm{Mn}, \mathrm{Co}$ and $\mathrm{Cu}$ content ICP-MS was the method of choice due to its excellent sensitivity and accuracy. Using principal component analysis (PCA), the samples of the studied legumes were classified into four groups according to their elemental composition.
\end{abstract}

Keywords: EDXRF; elemental composition; ICP-MS; legumes.

\section{Introduction}

Legumes are of prime importance in human or animal nutrition with a great variety of plants. ${ }^{1}$ These include crops grown for grains (e.g. common bean, runner bean, lupins, lentil, chickpea), fresh vegetables (e.g. snap bean, green pea) and livestock forage (e.g. soybean, field pea). Legumes play a distinct role in agricultural ecosystems with their ability to fix nitrogen symbiotically. ${ }^{2}$ Grains of food legumes are an important source of elements such as $\mathrm{P}, \mathrm{Ca}, \mathrm{K}, \mathrm{N}, \mathrm{Fe}, \mathrm{Mg}$ and $\mathrm{Zn}$, essential for a human well-being. Legume grains not only play a vital role in many traditional diets worldwide but are valuable for the food and animal feed industries. ${ }^{3}$ The common bean is the most important grain legume for direct human consumption which provides $10-20 \%$ of the adult requirements for nutrients, namely $\mathrm{Fe}, \mathrm{P}, \mathrm{Mg}, \mathrm{Mn}$, and to a lesser degree for $\mathrm{Zn}, \mathrm{Cu}$ and $\mathrm{Ca}^{4}{ }^{4}$ Chickpea applies the third most important grain legume for human consumption after beans and peas. ${ }^{5}$ According to the FAO, in 2019 the total world production was the highest for soybeans, followed by beans
(Phaseolus spp.), peas, chickpeas, lentils, faba beans and lupins. ${ }^{6}$

The main objective in multi-elemental analysis of foods is to ensure food quality and safety. Therefore, with the increased crop production to meet the growing demands, product quality becomes an important issue. ${ }^{7}$ Elemental fingerprinting has been proven effective way for quality and authentication of foods. ${ }^{8}$ Besides, it serves as an important tool for plant breeding programmes and nutritional biofortification purposes. ${ }^{9,10,11}$ Around twenty of the known elements are defined as essential since they act as important phytochemicals and have a significant role in the maintenance of human health. Essential elements are classified into macroelements or major minerals, namely $\mathrm{Na}, \mathrm{K}, \mathrm{Mg}, \mathrm{Ca}, \mathrm{Cl}, \mathrm{P}$ and $\mathrm{S}$, and microelements or trace minerals such as $\mathrm{Fe}, \mathrm{Cu}, \mathrm{Mn}, \mathrm{Zn}, \mathrm{Co}$ and Mo. ${ }^{12}$ The levels of these elements are measured to provide valuable nutritional information about foods. Over the past decade, with the development of advanced analytical techniques, the element composition of various food samples can be 
successfully measured using inductively coupled plasma-mass spectrometry (ICP-MS), energy dispersive X-ray fluorescence (EDXRF) spectroscopy, among others. ${ }^{13} \mathrm{Al}-$ though ICP-MS is frequently the most accurate technique for elemental analysis due to the simplicity, easily interpreted spectra and the exceptionally low limits of detection, on the other hand, requires expensive reagents, gases and laborious sample preparation. ${ }^{8}$ EDXRF spectroscopy is a good alternative to ICP-based methods, in which sample digestions are needed since hardly any sample treatment is required to carry out multi-elemental analysis in solid samples. Despite huge progress made in EDXRF instruments few works were published in the field of elemental characterization of organic matrices such as plant foods using this technique. Nevertheless, EDXRF is characterized by detections limits at the low $\mathrm{mg} / \mathrm{kg}$ level, which are about three orders of magnitude higher than those obtained by the ICP-MS method. ${ }^{14}$

Within the framework of the current studies at the Agricultural Institute of Slovenia, the capabilities of two analytical techniques, ICP-MS and EDXRF spectroscopy, were compared through the determination of elements in several legume samples. The present research aims to provide data on elemental composition of legumes usually produced and consumed in Slovenia which can be used in the ongoing plant breeding programs (e.g. common bean). The purpose of the study was: (i) to determine the multi-elemental composition of different legumes; (ii) to assess the appropriateness of two analytical methods ICPMS and EDXRF for element determination of different legumes, thus (iii) evaluating the correlation between used analytical methods.

\section{Experimental}

\section{1. Materials}

A set of twenty homogenised plant samples consists of several legume species as presented in Table 1. Analysed samples were as follows: common bean grains (6 samples), common bean pods (3 samples), lupin (3 samples), faba bean (2 samples), lentil (2 samples), chickpea (1 sample), soybean (1 sample), field pea (1 sample) and runner bean (1 sample). Most of the analysed legumes were produced at the experimental fields of Infrastructure Centre Jablje at the Agricultural Institute of Slovenia ( $304 \mathrm{~m}$ a.s.l.; $46.151^{\circ} \mathrm{N}$ $14.562^{\circ} \mathrm{E}$ ). Chickpea, brown and red lentil samples were purchased from the Slovenian food retail market. The legume grain samples were air-dried after harvest to reduce the moisture content, to levels below $11 \%$. The common bean pods were immediately after harvesting frozen using liquid nitrogen and lyophilized. Before determination of elements, all legume samples were homogenised and powdered using a laboratory ball mill (Retsch MM 400, $\mathrm{GmbH}$ ) at a high frequency of $30 \mathrm{~Hz}$ for $2-5 \mathrm{~min}$.

\section{2. Determination of Elements Using ICP-MS}

Digestion of plant samples (decomposition of organic matter). The powdered legume samples were digested using a high-pressure microwave oven (Milestone ETHOS 1600). Separate samples were weighed $(250 \mathrm{mg})$ into PTFE vessels and $6 \mathrm{~mL}$ of $65 \%$ nitric acid $\left(\mathrm{HNO}_{3}\right.$, SUPRAPUR, Merck) and $2 \mathrm{~mL} 30 \%$ hydrogen peroxide $\left(\mathrm{H}_{2} \mathrm{O}_{2}\right.$, SUPRAPUR, Merck) was added. The digestion was conduct-

Table 1. List of studied legume samples and their origin

\begin{tabular}{lllll}
\hline Sample name & Legume species & Latin name & $\begin{array}{l}\text { Variety/ } \\
\text { accession }\end{array}$ & Seed provider \\
\hline KIS_GL1 & common bean & Phaseolus vulgaris L. & Ribnčan & $\begin{array}{l}\text { Semenarna Ljubljana } \\
\text { type }\end{array}$ \\
KIS_GL2 & common bean & Phaseolus vulgaris L. & SRGB204 & Slovenian Plant Gene Bank \\
KIS_GL3 & common bean & Phaseolus vulgaris L. & Zorin & Semenarna Ljubljana \\
KIS_GL4 & common bean & Phaseolus vulgaris L. & Ribnčan & Semenarna Ljubljana \\
KIS_GL5 & common bean & Phaseolus vulgaris L. & SRGB204 & Slovenian Plant Gene Bank \\
KIS_GL6 & common bean & Phaseolus vulgaris L. & Zorin & Semenarna Ljubljana \\
KIS_GL7 & common bean & Phaseolus vulgaris L. & Etna & Semenarna Ljubljana \\
KIS_GL8 & common bean & Phaseolus vulgaris L. & Golden gate & Semenarna Ljubljana \\
KIS_GL9 & common bean & Phaseolus vulgaris L. & SRGB196 & Slovenian Plant Gene Bank \\
KIS_GL10 & white lupin & Lupinus albus L. & Energy & Feldsaaten Freudenberger \\
KIS_GL11 & faba bean & Vicia faba L. var. minor & Zoran & Agricultural Institute of Slovenia \\
KIS_GL12 & faba bean & Vicia faba L. var. minor & Merkur & Semenarna Ljubljana \\
KIS_GL13 & blue lupin & Lupinus angustifolius L. & Sonet & Feldsaaten Freudenberger \\
KIS_GL14 & yellow lupin & Lupinus luteus L. & Mister & Feldsaaten Freudenberger \\
KIS_GL15 & red lentil & Lens culinaris Medik. & rdeča leča & food retail market \\
KIS_GL16 & brown lentil & Lens culinaris Medik. & rjava leča & food retail market \\
KIS_GL17 & chickpea & Cirer arietinum L. & čičerika & food retail market \\
KIS_GL18 & soybean & Glycine max L. Merr. & ES Mentor & Saatbau Slovenia \\
KIS_GL19 & field pea & Pissum sativum L. & Eso & Semenarna Ljubljana \\
KIS_GL20 & runner bean & Phaseolus coccineus L. & SRGB222 & Slovenian Plant Gene Bank \\
\hline
\end{tabular}


ed according to the following programme: step 1, $300 \mathrm{~W}$, $5 \mathrm{~min}$ at $100{ }^{\circ} \mathrm{C}$; step $2,400 \mathrm{~W}, 5 \mathrm{~min}$ at $150^{\circ} \mathrm{C}$; step 3, $500 \mathrm{~W}, 5 \mathrm{~min}$ at $180^{\circ} \mathrm{C}$; step $4,600 \mathrm{~W}, 7 \mathrm{~min}$ at $210^{\circ} \mathrm{C}$; step 5, $550 \mathrm{~W}, 15 \mathrm{~min}$ at $210^{\circ} \mathrm{C}$; step $6,0 \mathrm{~W}, 20 \mathrm{~min}$ cooling.

Preparation of test solution. Digested samples were cooled to room temperature and the solution was quantitatively transferred into $50 \mathrm{~mL}$ plastic tubes (Sarstedt, USA) and filled up to full volume with Milli-Q water. Before analysis, the digested samples were diluted by a factor of 20 and consisted of $1 \% \mathrm{HNO}_{3}$ (v/v).

Determination of elements by ICP-MS. For the determination of elements in samples, the Agilent 7900 ICP-MS was used. This instrument includes a $4^{\text {th }}$ generation collision/reaction cell, the Octopole reaction System $\left(\mathrm{ORS}^{4}\right)$ which provides optimized operational conditions for the removal of polyatomic interferences using helium $(\mathrm{He})$ collision mode. In this manner, smaller and faster analyte ions are separated from larger, slower interference ions using kinetic energy discrimination. The following isotopes were monitored: ${ }^{23} \mathrm{Na},{ }^{24} \mathrm{Mg},{ }^{31} \mathrm{P},{ }^{34} \mathrm{~S},{ }^{39} \mathrm{~K},{ }^{43} \mathrm{Ca},{ }^{51} \mathrm{~V},{ }^{52} \mathrm{Cr}$, ${ }^{55} \mathrm{Mn},{ }^{56} \mathrm{Fe},{ }^{59} \mathrm{Co},{ }^{63} \mathrm{Cu},{ }^{66} \mathrm{Zn}$ and ${ }^{95} \mathrm{Mo}$. Due to the high sensitivity of the 7900 ICP-MS most elements of interest could be measured in He mode, only phosphorus $(\mathrm{P})$ and sulphur (S) were measured in the high helium (HEHe) mode. The ICP-MS operating conditions were optimized using autotuning functions within the ICP-MS MassHunter software. Other instruments operating conditions were as follows: general-purpose plasma mode; peri-pump sample introduction; micro-mist nebuliser; nickel cones interface; He gas flow was $5 \mathrm{~mL} / \mathrm{min}$ in He mode and $10 \mathrm{~mL} / \mathrm{min}$ in HEHe mode; spectrum acquisition mode; one point peak pattern; three replicates and 100 sweeps per replicate.

Calibration of the instrument. Quantitative analysis was performed with the external calibration method. Calibration standards for most of the elements were prepared using IV-STOCK-50 standard solution containing: $1000 \mathrm{mg} / \mathrm{L}$ of $\mathrm{Na}, \mathrm{Mg}, \mathrm{K}, \mathrm{Ca}$ and $\mathrm{Fe}$ and $10 \mathrm{mg} / \mathrm{L}$ of $\mathrm{V}, \mathrm{Cr}$, $\mathrm{Mn}, \mathrm{Co}, \mathrm{Cu}, \mathrm{Zn}$ and $\mathrm{Mo}$ (matrix $5 \% \mathrm{v} / \mathrm{v} \mathrm{HNO}_{3}$, Inorganic Ventures). Phosphorus (1000 mg/L P, matrix $\mathrm{H}_{2} \mathrm{O}$, CGP1, Inorganic Ventures) and sulphur $(1000 \mathrm{mg} / \mathrm{L} \mathrm{S}$, matrix $\mathrm{H}_{2} \mathrm{O}$, CGS1, Inorganic Ventures) single standard solutions were added separately to the mixture. A five-point calibration from $0.05 \mu \mathrm{g} / \mathrm{L}$ to $50 \mu \mathrm{g} / \mathrm{L}$ was carried out for the elements $\mathrm{V}, \mathrm{Cr}, \mathrm{Mn}, \mathrm{Co}, \mathrm{Cu}, \mathrm{Zn}$ and $\mathrm{Mo}$, and from $5 \mu \mathrm{g} / \mathrm{L}$ to $5000 \mu \mathrm{g} / \mathrm{L}$ for the elements Na, Mg, S, P, K and Fe. Only for Ca a six-point calibration was used between $5 \mu \mathrm{g} / \mathrm{L}$ and $10000 \mu \mathrm{g} / \mathrm{L}$ due to the higher concentrations expected in plant samples. Final multi-element calibration solutions were prepared daily and contained $1 \% \mathrm{HNO}_{3}(\mathrm{v} / \mathrm{v})$. The internal standards used to compensate for sensitivity drift and matrix effects during the analytical run were $\mathrm{Sc}, \mathrm{Rh}$, In and $\mathrm{Lu}$ (Agilent PN 5188-6525). They were added online in a concentration of $200 \mu \mathrm{g} / \mathrm{L}$ (in $1 \% \mathrm{v} / \mathrm{v} \mathrm{HNO}_{3}$ ).

Quality control. For quality control analytical blanks, independent QC standards and standard reference mate- rial (SRM) were used. In each test series, a blank sample containing only acids was included. The QC standards were prepared in the concentrations of $2 \mu \mathrm{g} / \mathrm{L}, 20 \mu \mathrm{g} / \mathrm{L}$ and $2000 \mu \mathrm{g} / \mathrm{L}$ over the analytical range from ICP-MS multi-standard solution VIII (MERCK, Certipur, PN 1.09492) and ICP-MS multi-standard solution XVI (MERCK, Certipur, PN 1.09487) and were analysed in the beginning, in the middle and at the end of each analysis run. Finally, a National Institute of Standards and Technology (NIST) Standard Reference Material (SRM) Tomato Leaves (1573a) was used to check the accuracy of the analytical procedures and recovery. Analytical data was processed using the ICP-MS MassHunter Workstation Software (Rev. C.01.02, G7201C, Agilent technologies, 2015). The software calculates the correlation coefficient of the calibration curve (R), the limit of detection (LOD) and the background equivalent concentration (BEC) for each element. Data along with the accuracy (as \% recovery) is shown in Table 2 and accuracy data using NIST SRM Tomato Leaves (1573a) in Table 3. The data are expressed as macro- $(\mathrm{g} / \mathrm{kg})$ or microelements $(\mathrm{mg} / \mathrm{kg})$.

Table 2. ICP-MS calibration coefficients, method detection limits and background equivalent concentration data

\begin{tabular}{lcccc}
\hline Element & $\boldsymbol{R}^{2}$ & $\begin{array}{c}\text { LOD } \\
(\mathbf{m g} / \mathbf{k g})\end{array}$ & $\begin{array}{c}\text { BEC } \\
(\mathbf{m g} / \mathbf{k g})\end{array}$ & $\begin{array}{c}\text { Recovery } \\
(\%)\end{array}$ \\
\hline${ }^{23} \mathrm{Na}$ & 1.0000 & 1.07 & 6.63 & 82.5 \\
${ }^{24} \mathrm{Mg}$ & 1.0000 & 0.53 & 0.74 & 84.9 \\
${ }^{31} \mathrm{P}$ & 1.0000 & 10.8 & 8.2 & 92.7 \\
${ }^{34} \mathrm{~S}$ & 1.0000 & 223 & 3360 & 95.7 \\
${ }^{39} \mathrm{~K}$ & 1.0000 & 6.8 & 318.0 & 91.4 \\
${ }^{43} \mathrm{Ca}$ & 1.0000 & 48 & 125 & 89.9 \\
${ }^{51} \mathrm{~V}$ & 1.0000 & 0.0001 & 0.0041 & 71.8 \\
${ }^{52} \mathrm{Cr}$ & 1.0000 & 0.085 & 0.342 & 86.6 \\
${ }^{55} \mathrm{Mn}$ & 1.0000 & 0.038 & 0.093 & 90.9 \\
${ }^{56} \mathrm{Fe}$ & 1.0000 & 0.021 & 3.522 & 86.3 \\
${ }^{59} \mathrm{Co}$ & 1.0000 & 0.003 & 0.035 & 85.8 \\
${ }^{63} \mathrm{Cu}$ & 1.0000 & 0.041 & 0.160 & 98.5 \\
${ }^{6} \mathrm{Zn}$ & 1.0000 & 0.254 & 0.759 & 89.7 \\
${ }^{95} \mathrm{Mo}$ & 1.0000 & 0.010 & 0.217 & 73.3 \\
\hline
\end{tabular}

$\mathrm{R}$, calibration coefficient; LOD, method detection limit; BEC, background equivalent concentration.

\section{3. Determination of Elements Using EDXRF}

Identification of twelve elements ( $\mathrm{P}, \mathrm{S}, \mathrm{Cl}, \mathrm{K}, \mathrm{Ca}, \mathrm{Ti}$, $\mathrm{Fe}, \mathrm{Zn}, \mathrm{Br}, \mathrm{Rb}, \mathrm{Sr}, \mathrm{Mo}$ ) in a single measurement was carried out using non-destructive EDXRF spectrometry. Pellets prepared from $0.5 \mathrm{~g}$ to $1.0 \mathrm{~g}$ of powdered legume samples were set using a pellet die and a hydraulic press. The disc radioisotope excitation sources $\mathrm{Fe}-55(25 \mathrm{mCi})$ and Cd-109 (20 mCi) from Eckert \& Ziegler (Germany) was used for fluorescence excitation. The emitted fluorescence 
radiation was measured using the EDXRF spectrometer with an XR-100 SDD detector (Amptek), a PX5 digital pulse processor (Amptek), and a PC-based, multichannel analyser software package DPPMCA. In Fe-55 mode, the spectrometer was equipped with a vacuum chamber to measure the three light elements (P, S, Cl), and in Cd-109 mode, the multi-element measurement was performed in the air for the nine elements $\mathrm{K}, \mathrm{Ca}, \mathrm{Ti}, \mathrm{Fe}, \mathrm{Zn}, \mathrm{Br}, \mathrm{Rb}, \mathrm{Sr}$ and Mo. The energy resolution setting of the spectrometer was $125 \mathrm{eV}$ at $5.9 \mathrm{keV}$. The analysis of complex X-ray spectra was performed using the AXIL spectral analysis program..$^{15}$ The evaluated uncertainty of this procedure included the statistical uncertainty of measured intensities and the uncertainty of the mathematical fitting procedure. The overall uncertainty of spectral measurement and analysis was in most cases better than $1 \%$.

Quantification was performed using the QAES (Quantitative Analysis of Environmental Samples) software. ${ }^{16}$ The estimated uncertainty of the analysis was around $5 \%$ to $10 \%$, LOD for $\mathrm{Zn}$ was from $5 \mu \mathrm{g} / \mathrm{g}$ to $10 \mu \mathrm{g} / \mathrm{g}$. A high total estimated uncertainty is mainly due to contributions of matrix correction and geometry calibration procedures, which include errors of tabulated fundamental parameters, and also contributions of spectrum acquisition and analysis. The uncertainty due to the inhomogeneity of the sample was not included. Accuracy of the data

Table 3. Accuracy of the data using the National Institute of Standards and Technology (NIST) Standard Reference Material (SRM) Tomato Leaves (1573a)

\begin{tabular}{|c|c|c|c|}
\hline \multirow[t]{2}{*}{ Element } & \multicolumn{3}{|c|}{ NIST SRM Tomato Leaves (1573a) } \\
\hline & $\begin{array}{r}\text { EDXRF } \\
\text { results }\end{array}$ & $\begin{array}{r}\text { ICP-MS } \\
\text { results }\end{array}$ & $\begin{array}{l}\text { Certified } \\
\text { values }\end{array}$ \\
\hline \multicolumn{4}{|c|}{$\mathrm{g} / \mathrm{kg}$} \\
\hline K & $27.80 \pm 0.28$ & $24.47 \pm 0.04$ & $26.76 \pm 0.48$ \\
\hline $\mathrm{P}$ & $1.930 \pm 0.023$ & $2.004 \pm 0.001$ & $2.161 \pm 0.028$ \\
\hline S & $8.82 \pm 0.90$ & $9.19 \pm 0.18$ & $9.60^{*}$ \\
\hline $\mathrm{Ca}$ & $50.10 \pm 0.49$ & $45.37 \pm 0.07$ & $50.45 \pm 0.55$ \\
\hline $\mathrm{Mg}$ & I & $10.18 \pm 0.01$ & $12.00^{\star}$ \\
\hline $\mathrm{Cl}$ & $6.50 \pm 0.65$ & I & $6.60^{*}$ \\
\hline \multicolumn{4}{|c|}{$\mathrm{mg} / \mathrm{kg}$} \\
\hline $\mathrm{Fe}$ & $353.0 \pm 3.6$ & $317.3 \pm 1.5$ & $367.5 \pm 4.3$ \\
\hline $\mathrm{Mn}$ & $246.1 \pm 2.8$ & $223.8 \pm 0.6$ & $246.3 \pm 7.1$ \\
\hline $\mathrm{Zn}$ & $29.10 \pm 3.01$ & $27.75 \pm 0.27$ & $30.94 \pm 0.55$ \\
\hline $\mathrm{Na}$ & I & $112.3 \pm 0.2$ & $136.1 \pm 3.7$ \\
\hline $\mathrm{Cu}$ & / & $4.63 \pm 0.02$ & $4.70 \pm 0.14$ \\
\hline $\mathrm{Rb}$ & $15.90 \pm 0.21$ & / & $14.83 \pm 0.31$ \\
\hline $\mathrm{Br}$ & $12.70 \pm 1.30$ & l & $13.00^{*}$ \\
\hline $\mathrm{Sr}$ & $83 \pm 9$ & I & $85^{\star}$ \\
\hline Mo & I & $0.34 \pm 0.1$ & $0.46^{*}$ \\
\hline $\mathrm{Cr}$ & I & $1.721 \pm 0.011$ & $1.988 \pm 0.034$ \\
\hline Co & I & $0.4952 \pm 0.0001$ & $0.5773 \pm 0.0071$ \\
\hline $\mathrm{V}$ & I & $0.599 \pm 0.005$ & $0.835 \pm 0.034$ \\
\hline
\end{tabular}

${ }^{*}$ noncertified values using the 1573a (Tomato Leaves) is presented in Table 3 . The quantified twelve elements were expressed as macro$(\mathrm{g} / \mathrm{kg})$ or microelements $(\mathrm{mg} / \mathrm{kg})$.

\section{4. Statistical Evaluation}

Statistical calculations and multivariate analysis were carried out using the XLSTAT software package (Addinsoft, New York, USA). The multivariate analysis involved principal component analysis (PCA).

\section{Results and Discussion}

A common characteristic of both analytical techniques applied ICP-MS and EDXRF is their multi-element capability. Preparation of legume samples was simple and non-destructive in the case of EDXRF, while, ICP-MS required skilled personnel and decomposition of samples. ICP-MS was a more sensitive method in this study with LODs in the range of $\mathrm{ng} / \mathrm{g}$. Results of the LOD, BEC and accuracy of multi-elemental determination performed by ICP-MS with certified reference material (NIST SRM Tomato Leaves 1573a) are presented in Tables $2 \& 3$. The sensitivity of EDXRF according to estimated uncertainty was from $5 \%$ to $10 \%$ and LODs for the analysed elements in the range from a hundred to a few $\mu \mathrm{g} / \mathrm{g}$. This means that LODs of ICP-MS were approximately two orders of magnitude lower compared to EDXRF. The determination of element $\mathrm{Cl}$ by ICP-MS was impossible since it forms negative ions, while EDXRF enables its determination as an essential element (dietary mineral) being one of the main electrolytes in the body. On the other hand, ICP-MS enables the determination of elements $\mathrm{Na}, \mathrm{Mg}, \mathrm{Mn}$ and $\mathrm{Cu}$ which are according to the European Food Safety Authority (EFSA) essential required substances as nutrients necessary by the body to perform a variety of functions. Considering the cost per sample, EDX$\mathrm{RF}$ was cheaper, simpler and more environmentally friendly when compared to ICP-MS and much more suitable for determination of $\mathrm{P}, \mathrm{S}, \mathrm{Cl}, \mathrm{K}, \mathrm{Ca}, \mathrm{Fe}, \mathrm{Zn}, \mathrm{Mo}, \mathrm{Sr}, \mathrm{Rb}, \mathrm{Ti}$ and $\mathrm{Br}$ in legume samples. However, for determination of $\mathrm{Na}, \mathrm{Mg}, \mathrm{V}$, $\mathrm{Cr}, \mathrm{Mn}, \mathrm{Co}$ and $\mathrm{Cu}$ content ICP-MS was a method of choice due to its excellent sensitivity and accuracy.

The macroelement composition of twenty legume samples determined by ICP-MS and/or EDXRF is presented in Table 4 and the microelement composition in Table 5. A total of nineteen elements were determined and divided into six macro- $(\mathrm{Mg}, \mathrm{P}, \mathrm{S}, \mathrm{K}, \mathrm{Cl}, \mathrm{Ca})$ and thirteen microelements ( $\mathrm{Mn}, \mathrm{Fe}, \mathrm{Cu}, \mathrm{Na}, \mathrm{Cr}, \mathrm{Co}, \mathrm{Zn}, \mathrm{V}, \mathrm{Rb}, \mathrm{Ti}, \mathrm{Br}, \mathrm{Sr}, \mathrm{Mo}$ ). The results of macroelements are expressed as $\mathrm{g} / \mathrm{kg}$ (Table 4 ) and those of microelements as $\mathrm{mg} / \mathrm{kg}$ (Table 5). Based on the average values the order is $\mathrm{K}>\mathrm{P}>\mathrm{S}>\mathrm{Ca}>\mathrm{Mg}>\mathrm{Cl}$ of for the macro- and $\mathrm{Fe}>\mathrm{Mn}>\mathrm{Zn}>\mathrm{Na}>\mathrm{Cu}>\mathrm{Rb}>\mathrm{Br}>\mathrm{Ti}$ $>\mathrm{Sr}>\mathrm{Mo}>\mathrm{Cr}>\mathrm{Co}>\mathrm{V}$ for the microelements in analysed legume samples. The ranges of individual macroelements in the analysed legumes were as follows: $\mathrm{K}(7.5-22.6 \mathrm{~g} / \mathrm{kg})$, 
$\mathrm{P}(2.7-7.5 \mathrm{~g} / \mathrm{kg}), \mathrm{S}(0.9-4.7 \mathrm{~g} / \mathrm{kg}), \mathrm{Ca}(0.2-5.0 \mathrm{~g} / \mathrm{kg}), \mathrm{Mg}$ $(0.8-2.9 \mathrm{~g} / \mathrm{kg})$, and $\mathrm{Cl}(0.1-51.0 \mathrm{~g} / \mathrm{kg})$. The highest coefficient of variation was calculated for the $\mathrm{Ca}(66.49 \%)$, followed by $\mathrm{Cl}$ (58.30\%) and S (38.40\%). Among different legume species, the highest concentrations of $\mathrm{K}$ was found in common bean pods (snap beans) and soybean grains and the lowest for lentil. The $\mathrm{P}$ concentration was the highest for faba bean and the lowest for chickpea. The lupins and soybean contained the most $\mathrm{S}$, and common bean pods the most $\mathrm{Ca}$. When compared with other legumes, lentil had the lowest concentration of $\mathrm{Ca}$ and $\mathrm{Mg}$. The ranges of essential microelements in the analysed legumes were the following: $\mathrm{Fe}(37.2-126.0 \mathrm{mg} / \mathrm{kg}), \mathrm{Mn}(8.3-487.7 \mathrm{mg} / \mathrm{kg}), \mathrm{Zn}$ (17.5-64.6 mg/kg), Na (1.7-91.8 mg/kg), Cu (4.9-16.3 mg/ $\mathrm{kg})$, and Mo $(0.2-8.5 \mathrm{mg} / \mathrm{kg})$. Among determined microelements the highest coefficients of variation were calculated for the $\mathrm{Mn}, \mathrm{Cr}$ and $\mathrm{Na}$ (> 102.12\%) while the lowest for $\mathrm{Cu}$, $\mathrm{Zn}$ and $\mathrm{Fe}(<38.72 \%)$. The highest concentration of Fe was found for soybean and the lowest for field peas. All three lupin samples (white, blue and yellow) were the richest source of microelement $\mathrm{Mn}$ compared to other legumes. The Na concentration was the highest for common bean pods and lupins. These elemental compositions are consistent with literature data for common bean grains ${ }^{17,18}$ and pods, ${ }^{19,20}$ lupin, ${ }^{21,22}$ faba bean, ${ }^{22,23}$ lentil, ${ }^{3,24,25}$ chickpea, ${ }^{3,5}$ soybean, ${ }^{21}$ field pea ${ }^{25}$ and runner bean. ${ }^{26,27}$

The EFSA set dietary reference values for the following fourteen essential elements $\mathrm{Ca}, \mathrm{Cl}, \mathrm{Cu}, \mathrm{F}, \mathrm{I}, \mathrm{Fe}, \mathrm{Mg}$, $\mathrm{Mn}, \mathrm{Mo}, \mathrm{P}, \mathrm{K}, \mathrm{Se}, \mathrm{Na}$ and $\mathrm{Zn}$. Using laboratorial developed
ICP-MS multi-element method for plant samples ten $(\mathrm{Ca}$, $\mathrm{Cu}, \mathrm{Fe}, \mathrm{Mg}, \mathrm{Mn}, \mathrm{Mo}, \mathrm{P}, \mathrm{K}, \mathrm{Na}, \mathrm{Zn}$ ) of these fourteen elements were determined. The three elements, namely $\mathrm{Cl}, \mathrm{F}$ and I, belong to halogen elements and for these due to the presence of interferences formed in the Ar plasma operating under conventional conditions or due to the matrix effects, their determination by ICP-MS is still considered a challenging task. Despite quadrupole ICP-MS is by far the most used instrumentation for multi-element determination, there are some drawbacks particularly associated with its application for halogen determination. ${ }^{28}$ Furthermore, the Se is another element which determination by ICP-MS remains particularly difficult. For Se analyses, conventional quadrupole ICP-MS operation suffers from inadequate sensitivity due to the high ionization potential of Se in the plasma as well as isobaric and polyatomic interferences. Selenium has six stable isotopes $\left({ }^{74} \mathrm{Se} 0.87 \%\right.$, ${ }^{76} \mathrm{Se} 9.02 \%,{ }^{77} \mathrm{Se} 0.58 \%,{ }^{78} \mathrm{Se} 23.52 \%,{ }^{80} \mathrm{Se} 49.82 \%,{ }^{82} \mathrm{Se}$ $9.19 \%)$, which adds complexity to the analysis. ${ }^{29}$ When using the EDXRF multi-element method seven $(\mathrm{Ca}, \mathrm{Cl}$, $\mathrm{Fe}, \mathrm{Mo}, \mathrm{P}, \mathrm{K}, \mathrm{Zn}$ ) of fourteen above mentioned elements was determined. However, EDXRF is a non-destructive and simultaneous method with simple sample preparation steps. ${ }^{30}$ After the sample preparation procedure, the EDX$\mathrm{RF}$ analysis presented high analytical frequency and most equipment counts on an automatic sample holder. ${ }^{31}$

Out of a total of nineteen elements determined using ICP-MS and EDXRF, the following seven P, S, K, Ca, $\mathrm{Fe}, \mathrm{Zn}$ and Mo were determined by both methods. The

Table 4. Macroelement composition of 20 legume samples determined by ICP-MS and EDXRF

\begin{tabular}{|c|c|c|c|c|c|c|c|c|c|c|c|}
\hline \multirow{3}{*}{$\begin{array}{l}\text { Sample } \\
\text { name }\end{array}$} & \multirow{3}{*}{$\begin{array}{l}\text { Legume } \\
\text { species }\end{array}$} & \multicolumn{10}{|c|}{ Macroelements $(\mathrm{g} / \mathrm{kg})$} \\
\hline & & \multicolumn{2}{|c|}{$\mathbf{K}$} & \multicolumn{2}{|c|}{$\mathbf{P}$} & \multicolumn{2}{|c|}{$\mathbf{S}$} & \multicolumn{2}{|c|}{$\mathrm{Ca}$} & \multirow{2}{*}{$\begin{array}{c}\text { Mg } \\
\text { ICP-MS }\end{array}$} & \multirow{2}{*}{$\begin{array}{c}\text { Cl } \\
\text { ED XRF }\end{array}$} \\
\hline & & ICP-MS & ED XRF & ICP-MS & ED XRF & ICP-MS & ED XRF & ICP-MS & ED XRF & & \\
\hline KIS_GL1 & $\mathrm{CB}$ (grains) & 13.9 & 12.8 & 4.8 & 5.0 & 2.1 & 1.9 & 1.0 & 0.8 & 1.4 & 0.2 \\
\hline KIS_GL2 & $\mathrm{CB}$ (grains) & 19.1 & 17.3 & 5.9 & 5.9 & 2.3 & 1.9 & 1.2 & 1.0 & 1.6 & 0.3 \\
\hline KIS_GL3 & CB (grains) & 14.4 & 13.1 & 5.0 & 4.6 & 2.2 & 1.4 & 0.9 & 0.9 & 1.5 & 0.1 \\
\hline KIS_GL4 & CB (pods) & 17.1 & 18.3 & 3.1 & 3.5 & 1.4 & 1.2 & 2.5 & 2.2 & 1.7 & 0.7 \\
\hline KIS_GL5 & CB (pods) & 18.5 & 18.7 & 3.1 & 3.9 & 1.7 & 1.5 & 4.1 & 3.3 & 2.0 & 0.6 \\
\hline KIS_GL6 & $\mathrm{CB}$ (pods) & 20.9 & 22.6 & 3.7 & 4.7 & 1.5 & 1.8 & 5.0 & 3.7 & 2.1 & 1.0 \\
\hline KIS_GL7 & CB (grains) & 13.5 & 13.4 & 4.2 & 4.5 & 2.0 & 1.5 & 1.3 & 1.1 & 1.5 & 0.1 \\
\hline KIS_GL8 & CB (grains) & 16.3 & 15.4 & 5.9 & 5.8 & 2.4 & 2.1 & 1.2 & 1.1 & 1.7 & 0.3 \\
\hline KIS_GL9 & CB (grains) & 17.8 & 15.9 & 5.9 & 5.6 & 2.2 & 1.7 & 0.8 & 0.9 & 1.7 & 0.1 \\
\hline KIS_GL10 & white lupin & 15.3 & 11.9 & 5.3 & 6.2 & 2.4 & 2.5 & 3.0 & 1.8 & 1.7 & 0.1 \\
\hline KIS_GL11 & faba bean & 12.5 & 11.4 & 6.5 & 6.5 & 1.5 & 0.9 & 1.1 & 0.9 & 1.4 & 0.6 \\
\hline KIS_GL12 & faba bean & 12.7 & 12.9 & 6.2 & 6.5 & 1.6 & 1.1 & 1.0 & 1.0 & 1.4 & 0.5 \\
\hline KIS_GL13 & blue lupin & 11.1 & 10.4 & 4.9 & 4.9 & 2.2 & 2.0 & 2.2 & 2.1 & 1.8 & 0.2 \\
\hline KIS_GL14 & yellow lupin & 12.1 & 11.6 & 7.5 & 7.0 & 4.7 & 4.6 & 1.9 & 1.6 & 2.9 & 0.6 \\
\hline KIS_GL15 & red lentil & 9.2 & 9.1 & 3.7 & 3.5 & 1.8 & 1.5 & 0.2 & 0.2 & 0.8 & 0.5 \\
\hline KIS_GL16 & brown lentil & 7.8 & 7.5 & 3.1 & 3.1 & 1.6 & 1.2 & 0.8 & 0.8 & 0.8 & 0.7 \\
\hline KIS_GL17 & chickpea & 10.1 & 9.4 & 2.9 & 2.7 & 2.1 & 1.4 & 1.3 & 1.1 & 1.3 & 0.6 \\
\hline KIS_GL18 & soybean & 18.2 & 17.1 & 5.5 & 4.9 & 3.0 & 2.5 & 1.8 & 1.6 & 2.4 & 0.1 \\
\hline KIS_GL19 & field pea & 9.1 & 8.8 & 3.7 & 3.6 & 1.6 & 1.3 & 0.9 & 0.8 & 1.3 & 0.5 \\
\hline KIS_GL20 & runner bean & 17.8 & 16.3 & 4.6 & 5.1 & 2.0 & 2.3 & 1.1 & 1.2 & 1.8 & 0.5 \\
\hline \multicolumn{2}{|c|}{ Correlation } & \multicolumn{2}{|c|}{0.96} & \multicolumn{2}{|c|}{0.94} & \multicolumn{2}{|c|}{0.94} & \multicolumn{2}{|c|}{0.98} & n.a. & n.a. \\
\hline \multicolumn{2}{|c|}{ Coefficient of variation (\%) } & \multicolumn{2}{|c|}{26.85} & \multicolumn{2}{|c|}{25.54} & \multicolumn{2}{|c|}{38.40} & \multicolumn{2}{|c|}{66.49} & 29.27 & 58.30 \\
\hline
\end{tabular}

$\mathrm{CB}$, common bean; n.a., not applicable. 
Table 5. Microelement composition of 20 legume samples determined by ICP-MS and EDXRF

\begin{tabular}{|c|c|c|c|c|c|c|c|c|c|c|c|c|c|c|c|c|c|}
\hline \multirow{2}{*}{$\begin{array}{l}\text { Sample } \\
\text { name }\end{array}$} & \multirow{2}{*}{$\begin{array}{l}\text { Legume } \\
\text { species }\end{array}$} & \multicolumn{16}{|c|}{ Microelements (mg/kg) } \\
\hline & & $\begin{array}{c}\text { Fe } \\
\text { ICP- } \\
\text { MS }\end{array}$ & $\begin{array}{c}\text { ED } \\
\text { XRF }\end{array}$ & $\begin{array}{c}\text { Mn } \\
\text { ICP- } \\
\text { MS }\end{array}$ & $\begin{array}{c}\mathrm{Zn} \\
\text { ICP- } \\
\text { MS }\end{array}$ & $\begin{array}{c}\text { ED } \\
\text { XRF }\end{array}$ & $\begin{array}{c}\mathrm{Na} \\
\mathrm{ICP}- \\
\mathrm{MS}\end{array}$ & $\begin{array}{c}\mathrm{Cu} \\
\mathrm{ICP}- \\
\mathrm{MS}\end{array}$ & $\begin{array}{c}\text { Rb } \\
\text { ED } \\
\text { XRF }\end{array}$ & $\begin{array}{c}\text { Br } \\
\text { ED } \\
\text { XRF }\end{array}$ & $\begin{array}{c}\text { Ti } \\
\text { ED } \\
\text { XRF }\end{array}$ & $\begin{array}{c}\text { Sr } \\
\text { ED } \\
\text { XRF }\end{array}$ & $\begin{array}{c}\text { Mo } \\
\text { ICP- } \\
\text { MS }\end{array}$ & $\begin{array}{c}\text { ED } \\
\text { XRF }\end{array}$ & $\begin{array}{c}\text { Cr } \\
\text { ICP- } \\
\text { MS }\end{array}$ & $\begin{array}{c}\text { Co } \\
\text { ICP- } \\
\text { MS }\end{array}$ & $\begin{array}{c}\text { V } \\
\text { ICP- } \\
\text { MS }\end{array}$ \\
\hline S_GL1 & ins) & 64.6 & 69.2 & 12.0 & 28.1 & 26.6 & 6.1 & 8.7 & 5.9 & 1.3 & 1.6 & 0.9 & 0.6 & 0.9 & 0.2 & 0.03 & 0.003 \\
\hline KIS_GL2 & CB (grains) & 69.9 & 79.0 & 12.4 & 27.9 & 26.7 & 3.3 & 9.5 & 3.7 & 1.2 & 2.2 & 0.9 & 3.2 & 1.9 & 0.1 & 0.04 & 0.000 \\
\hline KIS_GL3 & CB (grains) & 57.7 & 91.6 & 11.0 & 28.9 & 22.3 & 2.4 & 5.9 & 9.0 & 1.7 & 3.5 & 1.1 & 0.9 & 0.9 & 0.3 & 0.03 & 0.004 \\
\hline KIS_GL4 & $\mathrm{CB}$ (pods) & 54.0 & 65.8 & 13.6 & 21.5 & 17.5 & 67.2 & 7.1 & 6.2 & 6.9 & 3.5 & 3.0 & 0.4 & 1.1 & 0.1 & 0.03 & 0.026 \\
\hline KIS_GL5 & $\mathrm{CB}$ (pods) & 44.2 & 76.6 & 14.7 & 22.0 & 23.9 & 53.5 & 5.8 & 3.9 & 2.9 & 4.4 & 4.1 & 0.2 & 1.3 & 0.1 & 0.02 & 0.002 \\
\hline KIS_GL6 & CB (pods) & 50.6 & 68.0 & 16.7 & 24.2 & 25.4 & 91.8 & 4.9 & 8.2 & 13.9 & 3.3 & 4.8 & 0.4 & 1.8 & 0.2 & 0.02 & 0.014 \\
\hline KIS_GL7 & CB (grains) & 77.3 & 84.0 & 13.6 & 26.8 & 25.1 & 3.0 & 8.3 & 2.4 & 1.5 & 3.0 & 4.6 & 5.8 & 4.5 & 0.2 & 0.04 & 0.045 \\
\hline KIS_GL8 & CB (grains) & 58.7 & 76.0 & 11.9 & 27.6 & 27.1 & 38.3 & 5.8 & 7.8 & 1.8 & 2.4 & 3.1 & 8.5 & 6.6 & 0.2 & 0.15 & 0.019 \\
\hline KIS_GL9 & CB (grains) & 56.9 & 84.7 & 9.4 & 20.3 & 19.4 & 1.7 & 5.2 & 6.7 & 1.6 & 3.8 & 0.8 & 4.7 & 3.5 & 0.2 & 0.05 & 0.008 \\
\hline KIS_GL10 & white lupin & 37.2 & 57.5 & 487.7 & 42.4 & 48.6 & 58.8 & 8.0 & 23.3 & 2.0 & 2.0 & 2.0 & 2.2 & 1.6 & 0.1 & 0.09 & 0.008 \\
\hline KIS_GL11 & faba bean & 43.3 & 74.7 & 16.4 & 49.1 & 43.1 & 9.0 & 16.3 & 5.6 & 1.3 & 2.0 & 0.9 & 0.9 & 1.1 & 0.2 & 0.20 & 0.005 \\
\hline KIS_GL12 & faba & 46.9 & 84.9 & 16.8 & 44.6 & 43.0 & 10.0 & 16.3 & 3.4 & 1.5 & 2.1 & 1.8 & 1.0 & 0.9 & 0.2 & 0.16 & 0.007 \\
\hline KIS_GL13 & blue lupin & 43.9 & 58.3 & 79.5 & 34.9 & 33.1 & 58.6 & 6.1 & 8.9 & 3.5 & 2.4 & 5.7 & 1.7 & 1.4 & 1.7 & 0.04 & 0.031 \\
\hline KIS_GL14 & yellow lupin & 64.9 & 95.6 & 82.9 & 63.3 & 64.6 & 78.3 & 10.7 & 3.3 & 2.1 & 4.1 & 2.2 & 1.4 & 1.1 & 2.9 & 0.07 & 0.022 \\
\hline KIS_GL15 & red lentil & 65.9 & 87.6 & 13.6 & 33.0 & 33.0 & 10.7 & 9.1 & 4.1 & 3.8 & 2.7 & 1.8 & 5.3 & 4.4 & 0.1 & 0.03 & 0.008 \\
\hline KIS_GL16 & brown lent & 47.3 & 70.8 & 9.6 & 19.6 & 22.1 & 6.9 & 8.1 & 3.1 & 1.3 & 2.8 & 1.8 & 0.5 & 0.9 & 0.2 & 0.04 & 0.006 \\
\hline KIS_GL17 & chickpea & 55.5 & 71.1 & 25.8 & 28.6 & 26.0 & 33.8 & 8.0 & 6.7 & 10.8 & 0.6 & 5.5 & 2.7 & 1.7 & 1.0 & 0.12 & 0.027 \\
\hline KIS_GL18 & soybean & 86.0 & 126.0 & 22.7 & 36.8 & 35.9 & 10.3 & 13.4 & 7.6 & 6.6 & 3.7 & 2.0 & 0.7 & 2.0 & 2.7 & 0.13 & 0.034 \\
\hline KIS_GL19 & field pea & 46.8 & 79.3 & 8.3 & 26.3 & 24.3 & 16.2 & 7.3 & 4.9 & 1.6 & 1.1 & 1.8 & 0.6 & 1.0 & 0.2 & 0.03 & 0.027 \\
\hline KIS_GL20 & runner bean & 52.7 & 77.6 & 12.6 & 23.0 & 20.8 & 1.8 & 5.4 & 3.4 & 2.6 & 1.0 & 2.6 & 2.4 & 1.9 & 0.3 & 0.04 & 0.013 \\
\hline oefficien & ff variation (\%) & & & & & & $\begin{array}{c}\text { n.a. } \\
102.12\end{array}$ & $\begin{array}{c}\text { n.a. } \\
38.72\end{array}$ & $\begin{array}{c}\text { n.a. } \\
68.38\end{array}$ & $\begin{array}{c}\text { n.a. } \\
97.13\end{array}$ & $\begin{array}{c}\text { n.a. } \\
39.79\end{array}$ & $\begin{array}{c}\text { n.a. } \\
59.72\end{array}$ & 89. & & $\begin{array}{c}\text { n.a. } \\
146.10\end{array}$ & $\begin{array}{c}\text { n.a. } \\
077.30\end{array}$ & $\begin{array}{c}\text { n.a. } \\
79.13\end{array}$ \\
\hline
\end{tabular}

$\mathrm{CB}$, common bean; n.a., not applicable.
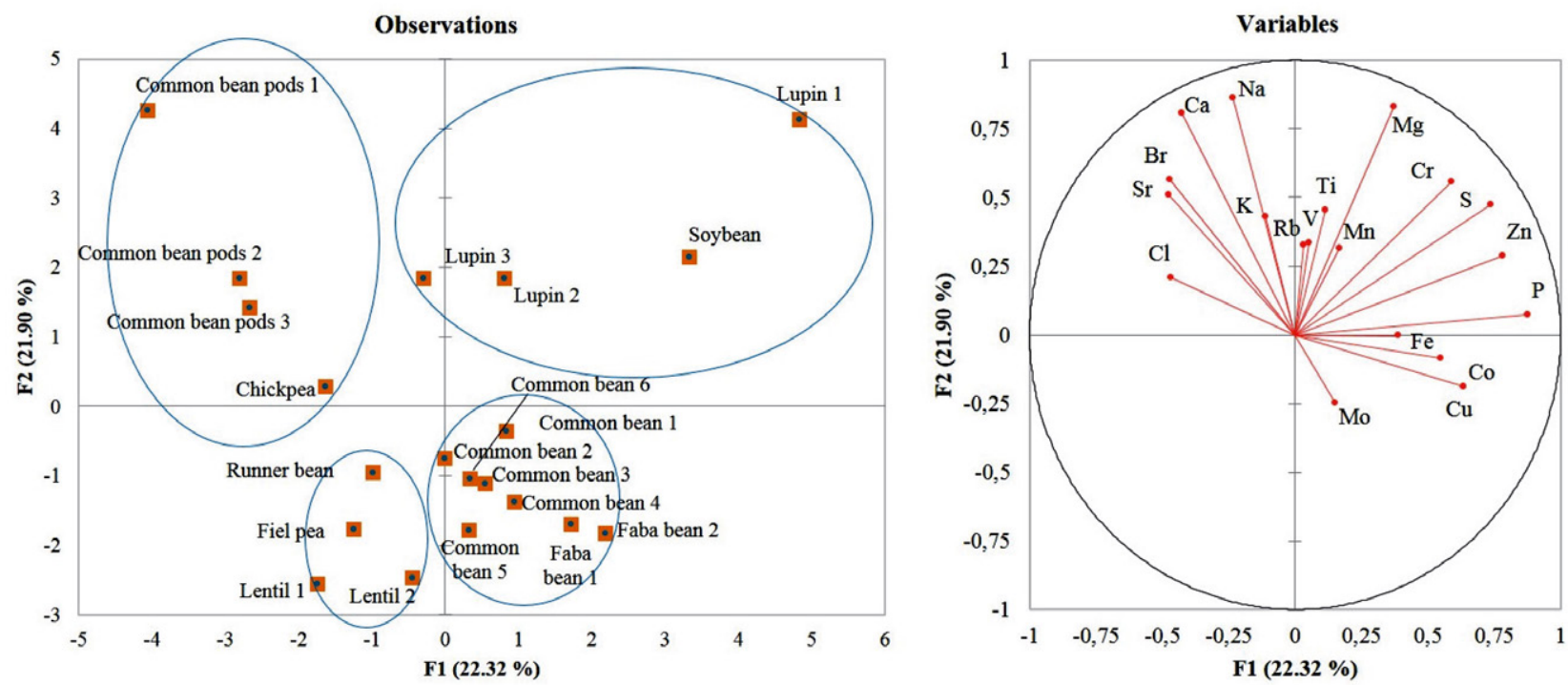

Fig. 1. PCA score plot (left) and discriminant loadings plot (right)

correlations between these two methods for the macroelements P, S, K and Ca are presented in Table 4 and for the microelements $\mathrm{Fe}, \mathrm{Zn}$ and Mo in Table 5. A very strong correlations were detected for the elements $\mathrm{Ca}(0.98), \mathrm{Zn}$ (0.97), K (0.96), Mo (0.95), P and S (0.94), while strong correlation was observed for $\mathrm{Fe}(0.72)$. For the elements $\mathrm{K}$,
S, Ca and Zn brought to evidence a tendency that EDXRF values were lower, when compared with ICP-MS values. Phosphorus values were comparable between methods while Fe EDXRF values were higher compared to ICP-MS values. These discrepancies can be due to the inhomogeneity of the samples. 
Statistical evaluation of results was performed on the dataset using PCA to identify the elements responsible for differentiating legume samples. The discrimination score plot and loadings across the original dataset are shown in Fig. 1. When the PCA was applied to the data (20 samples, 19 variables), discriminant functions were obtained where Function 1 explained 22.31\% and Function 2 21.90\% of the total variance. According to the multi-elemental composition, the analysed legumes can be divided into four groups as seen in Fig. 1. The first group included samples of common bean pods and chickpea with the most influential elements $\mathrm{Ca}, \mathrm{Na}, \mathrm{Sr}$ and $\mathrm{Cl}$. Second group involved soybean and lupin samples, where the most influential elements were $\mathrm{Na}, \mathrm{Mg}, \mathrm{S}, \mathrm{Zn}$ and $\mathrm{P}$. The third group consisted of runner bean, field pea and lentil samples with most influential elements $\mathrm{Mg}, \mathrm{S}, \mathrm{Zn}$ and P. Finally, the faba bean and common bean grain samples formed the fourth group with most influential elements $\mathrm{Mo}, \mathrm{Cu}$ and $\mathrm{Co}$.

\section{Conclusion}

There is a need for reliable legumes element concentration data to provide information about nutritional uptake, especially for essential macro- and microelements. Besides, the multi-elemental composition, it provides important information for the plant breeding programmes and can potentially serve as a base for nutrient biofortification purposes (e.g. Fe, $\mathrm{Zn}$ ). This paper provides some interesting comparisons between two different techniques (ICP-MS, EDXRF) in the determination of the multi-elemental composition of different legumes. An intercomparison of seven elements ( $\mathrm{P}, \mathrm{S}, \mathrm{K}, \mathrm{Ca}, \mathrm{Fe}, \mathrm{Zn}$ and $\mathrm{Mo}$ ) showed satisfactory agreement between both methods. The simple, fast and cheaper EDXRF method when combined with ICP-MS, was found the most appropriate technique for determination of $\mathrm{Na}, \mathrm{Mg}, \mathrm{V}, \mathrm{Cr}, \mathrm{Mn}, \mathrm{Co}$ and $\mathrm{Cu}$, and used to provide the first evaluation of multi-elemental composition to differentiate between several legume samples usually produced and consumed in Slovenia. Despite these encouraging data, there remain some limitations and further research base on a larger dataset of legume species will be important in establishing more reliable databases in elemental composition.

\section{Acknowledgements}

This research was a part of the research programme Agrobiodiversity (P4-0072) and the research project L47520 financially supported by the Slovenian research agency (ARRS), Ljubljana, Slovenia, and the Public Service in vegetables and herbs financed by the Ministry of Agriculture, Forestry and Food, Republic of Slovenia. The authors would like to thank Peter Kump, PhD, for kindly providing the QAES (Quantitative Analysis of Environmental Samples) software (XRF), and to the national curator of SPGB
(Slovene Plant Gene Bank) Jelka Šuštar Vozlič, PhD, for providing the legumes genetic resources.

\section{Reference}

1. E. Röös, G. Carlsson, F. Ferawati, M. Hefni, A. Stephan, P. Tidåker, C. Witthöft, Renew. Agr. Food Syst. 2020, 35(2), 192 205. DOI:10.1017/S1742170518000443

2. D. Rubiales, A. Mikić, Crit. Rev. Plant Sci., 2015, 34, $2-3$. DOI:10.1080/07352689.2014.897896

3. M. Farooq, M. Hussain, M. Usman, S. Farooq, S. S. Alghamdi, K. H. Siddique, J. Agric. Food Chem. 2018, 66(34), 88878897. DOI:10.1021/acs.jafc.8b02924

4. C. Pinheiro, J. P. Baeta, A. M. Pereira, H. Domingues, C. P. Ricardo, J. Food Comp. Anal. 2010, 23(4), 319-325. DOI:10.1016/j.jfca.2010.01.005

5. K. I. Ereifej, G. N. Al-Karaki, M. K., Hammouri, Int. J. Food Prop. 2001, 4(2), 239-246. DOI:10.1081/JFP-100105190

6. FAOSTAT, 2020. Food and Agriculture Organisation (FAO) of the United Nations. Crops. Avaialble form: http://www.fao. org/faostat/en/\#data/QC (Accessed on 8/4/2021).

7. G. Alandia, C. Pulvento, M. H. Sellami, N. Hoidal, T. Anemone, E. Nigussie, J. J. Agüero, A. Lavini, S. E. Jacobsen, in: A. Hirich, R. Choukr-Allah, R. Ragab (Eds.): Emerging Research in Alternative Crops, Environment \& Policy, vol 58. Springer, Cham, 2020, 25-53.

DOI:10.1007/978-3-319-90472-6_2

8. M. Markiewicz-Keszycka, R. Cama-Moncunill, M. P. Casado-Gavalda, C. Sullivan, P. J. Cullen, Curr. Opin. Food Sci. 2019, 28, 96-103. DOI:10.1016/j.cofs.2019.10.002

9. S. Kumar, G. Pandey, Heliyon 2020, 6(3), p.e03682. DOI:10.1016/j.heliyon.2020.e03682

10. B. M. Freire, R. M. Pereira, C. N. Lange, B. L. Batista, in: Sustainable Solutions for Elemental Deficiency and Excess in Crop Plants. Springer, Singapore. 2020, pp. 135-182. DOI:10.1007/978-981-15-8636-1_7

11. N. Petry, E. Boy, J. P. Wirth, R. F. Hurrell, Nutrients, 2015, 7(2), 1144-1173. DOI:10.3390/nu7021144

12. M. A. Zoroddu, J. Aaseth, G. Crisponi, S. Medici, M. Peana, V. M. Nurchi, J. Inorg. Biochem. 2019, 195, 120-129. DOI:10.1016/j.jinorgbio.2019.03.013

13. H. Zhao, J. Tang, Q. Yang, J. Food Comp. Anal. 2021, p.103900. DOI:10.1016/j.jfca.2021.103900

14. M. Ghidotti, S. Papoci, C. Dumitrascu, T. Zdiniakova, Y. Fiamegos, M. B. de la Calle Gutiñas, Talanta Open, 2021, p.100040. DOI:10.1016/j.talo.2021.100040

15. M. Nečemer, P. Kump, J. Ščančar, R. Jaćimović, J. Simčič, P. Pelicon, M. Budnar, Z. Jeran, P. Pongrac, Spectrochim. Acta B 2008, 63, 1240-1247. DOI:10.1016/j.sab.2008.07.006

16. M. Nečemer, P. Kump, K. Vogel-Mikuš, in: Use of X-ray fluorescence-based analytical techniques in phytoremediation, Nova Science Publishers, Inc., New York, USA, 2011, 331-358

17. A. P. de Oliveira, B. D. S. O. Mateó, A. M. Fioroto, P. V. de Oliveira, J. Naozuka, J. Food Comp. Anal. 2018, 67, 135-140. DOI:10.1016/j.jfca.2018.01.012 
18. G. E. Guild, N. G. Paltridge, M. S. Andersson, J.C. Stangoulis, Plant Soil 2017, 419(1), 457-466. DOI:10.1007/s11104-017-3352-4

19. G. R. Gomes, G. H. Freiria, L. Vinicius Constantino, S. M. Alves, D. M. Zeffa, L. S. A. Takahashi, Semina: Ciênc. Agrár. 2020, 41(5), 1469-1482. DOI:10.5433/1679-0359.2020v41n5p1469

20. T. Celmeli, H. Sari, H. Canci, D. Sari, A. Adak, T. Eker, C. Toker, Agronomy 2018, 8(9), p.166.

DOI:10.3390/agronomy8090166

21. S. Lukin, Vestnik Russian Agric. Sci. 2018, 6, 76-79. DOI:10.30850/vrsn/2018/6/76-79

22. C. I. Lizarazo, M. Yli-Halla, F. L. Stoddard, Nutr. Cycl. Agroecosystems 2015, 103(3), 311-327. DOI:10.1007/s10705-015-9743-0

23. H. Khazaei, A. Vandenberg, Agronomy 2020, 10(4), p.511. DOI:10.3390/agronomy10040511

24. Z. Türk, J. Plant Nutr. 2020, 43(4), 563-577. DOI:10.1080/01904167.2019.1685099

25. G. Ciurescu, I. Toncea, M. Ropotă, M. Hăbeanu, Rom. Agric. Res. 2018, 35, 101-108. https:/www.incda-fundulea.ro/rar/ nr35/rar35.14.pdf
26. L. X. Lopez-Martinez, in: H. N. Murthy, K. Y. Paek (Eds.) Bioactive Compounds in Underutilized Vegetables and Legumes. Reference Series in Phytochemistry. Springer, Cham, 2020, 1-17. DOI:10.1007/978-3-030-44578-2_31-1

27. M. T. Mosisa, Afr. J. Food Sci. 2017, 11(3), 74-81. DOI:10.5897/AJFS2016.1475

28. E. M. Flores, P. A. Mello, S. R. Krzyzaniak, V. H. Cauduro, R. S. Picoloto, Rapid Commun. Mass Spectrom. 2020, 34, p.e8727. DOI:10.1002/rcm.8727

29. M. W. Donner, T. Siddique, Can. J. Chem. 2018, 96(8), 795802. DOI:10.1139/cjc-2017-0637

30. G. G. A. de Carvalho, M. B. B. Guerra, A. Adame, C. S. Nomura, P. V. Oliveira, H. W. P. de Carvalho, D. Santos, L. C. Nunes, F. J. Krug, J. Anal. Atom. Spectrom. 2018, 33(6), 919944. DOI:10.1039/C7JA00293A

31. E. de Almeida, N. M. Duran, M. H. Gomes, S. M. Savassa, T. N. da Cruz, R. A. Migliavacca, H. W. Pereira de Carvalho, $X-$ Ray Spectrometry 2019, 48(2), 151-161.

DOI:10.1002/xrs.3001

\section{Povzetek}

$\mathrm{V}$ raziskavi smo z dvema analiznima tehnikama, induktivno sklopljeno plazemsko-masno spektrometrijo (ICP-MS) in energijsko disperzijsko rentgensko fluorescenčno spektroskopijo (EDXRF), določili elementarno sestavo različnih stročnic, ki se pogosto pridelujejo in uživajo v Sloveniji. Rezultati kažejo, da se podatki, pridobljeni z uporabo teh metod, dobro ujemajo s certificiranimi referenčnimi materiali. Skupno smo v dvajsetih vzorcih stročnic določili devetnajst elementov. Medsebojna primerjava štirih makro- (P, S, K, Ca) in treh mikroelementov (Fe, Zn, Mo) izmerjenih z ICP-MS in EDXRF, je pokazala visoko korelacijo med uporabljenima metodama. EDXRF se je izkazala za cenejšo, enostavnejšo in okolju prijaznejšo metodo za določanje elementov $\mathrm{P}, \mathrm{S}, \mathrm{Cl}, \mathrm{K}, \mathrm{Ca}, \mathrm{Fe}, \mathrm{Zn}, \mathrm{Mo}, \mathrm{Sr}, \mathrm{Rb}$, Ti in $\mathrm{Br}$ v stročnicah, medtem ko je za določanje vsebnosti $\mathrm{Na}, \mathrm{Mg}, \mathrm{V}, \mathrm{Cr}, \mathrm{Mn}$, Co in Cu ustreznejša ICP-MS metoda, predvsem zaradi visoke občutljivosti in natančnosti. Z analizo glavnih komponent (PCA) smo uspeli razvrstiti vzorce preučevanih stročnic glede na elementarno sestavo v štiri skupine.

Except when otherwise noted, articles in this journal are published under the terms and conditions of the Creative Commons Attribution 4.0 International License 